\title{
POVERTY AND INEQUALITY IN CONTEMPORARY PORTUGAL: IMPACT OF THE AUSTERITY POLICIES AND LESSONS FOR THE FUTURE
}

Abstract: In the European Union, Portugal is one of the countries with the highest levels of poverty and inequality. This is the reality that this article focuses on. The text provides statistical data that illustrate the evolution of poverty and income inequalities over the last decade (2011-2019), serving as a basis for a critical analysis of the consequences of economic cycles on it. In particular, how the combination of the economy (financial crisis), politics (austerity plan) and social context (low social contestation) has interfered with its worsening over the period 2011-2014. From this analysis, we develop the argument that if the negative alliance of the three factors makes a country poorer and more unequal, it is in turn the positive combination of the same factors that could lead to important advances in the fight against poverty and social inequality.

Keywords: Portugal; poverty; income inequality; economic cycles; statistics

\section{Introduction}

Social inequality, poverty, but also social exclusion, challenge any society to show the best it can achieve in terms of collective mobilization, the consolidation of democracy and the promotion of social cohesion. It is not possible to coexist the aspiration for a healthy democracy with the simultaneous tolerance of high social inequalities and unacceptable poverty rates. However, in Portugal, feelings of denial about the seriousness of these social problems are common, associated with the shame of the situations and the responsibility of the other. The expressions that "there are no poor people", "inequality has already been worse", "they are excluded because they want to" are recurrent. This, in turn, contrasts with the statistical finding that the country still has high levels of poverty and inequality. In the context of the 28 countries that compose the European Union, of which Portugal has been a member since 1986, the country has the 13th highest at-risk-of-poverty rate. But it is mainly at the level of income distribution inequality that the country appears in a more unfavourable situation, with the 10th highest value (date from 2018. Source: INE - Statistics Portugal).

\footnotetext{
${ }^{1}$ alcidesmonteiro@ubi.pt
} 
Portugal's last decade, between 2011 and 2019, was marked by two very distinct cycles. During the first half of the decade, the country experienced a strong financial and social crisis, in the course of a process in which the country's government was forced to ask international lenders (Troika: EU Commission, IMF - International Money Found and ECB - European Central Bank) for help to avoid bankruptcy and regain its international credibility. The scenario faced was that of a negative coalition of three factors, which had direct consequences on the worsening of poverty and inequality throughout this period: on the one hand, the application of a series of "structural adjustment" reforms imposed by the Troika; on the other, the way in which the national government used the crisis argument to implement some measures that, in another context, would not have the support of the population; and, finally, the fact that Portuguese society did not oppose head-on the application of austerity measures, resigning itself to an impoverishment that affected above all those who were already more vulnerable. From 2015 on the scenario is reversed, the country comes out of the crisis and liberates itself from the tutelage imposed by the Troika, the economic recovery begins and the levels of poverty and inequality take up again a downward trend. However, it is clear that this reversal is mainly the result of the favourable economic climate and not so much of a political programme or civic mobilisation to tackle and overcome those social problems.

Portugal, in its recent history, can be observed as an example of the relationship between economic cycles and the evolution of poverty and inequality. But at the same time it reveals that it is not only the economy but also political decisions and social dynamics that contribute to growth or the decrease in inequality levels. Consequently, we have established a double objective for this text: on the one hand, to provide a portrait of the evolution of the phenomena of poverty and inequality over the last decade in Portugal, in the two moments that characterize it; on the other hand, to analyse how the combination between the economy, political decisions and social context interfere with the aforementioned evolution. In this last point, our argument is that if the negative alliance of the three factors makes a country poorer and more unequal, it is in turn the positive combination of the same factors that may lead to important advances in the fight against poverty and social inequality.

\section{Portugal, 2011-2019: the economic cycles and the evolution of poverty and inequalities}

Portugal joined the so-called European Economic Community (EEC) on 1 January 1986. Between that year and 1991, the country benefited from a transitional period, as the country's level of development was lower than that of the other member states. In order to overcome this inequality, Portugal received structural funds from the EEC that allowed national governments to undertake the necessary reforms in the modernisation of the productive sector, the creation of infrastructures, the improvement of health services and the expansion of the educational network, among others. In this period, and in subsequent ones, the evolution of the Portuguese economy as well as the living conditions of the populations were clearly positive. Even so, it was not sufficient to guarantee its levelling with that of other member states (Cunha \& Braz, 2009). As an example, in 1995 the country's GDP per capita was equivalent to $79 \%$ of the European Union average 
(considering the 28 countries that were part of it in January 2020). And in 2018 the GDP per capita corresponded to $77 \%$ of the same European average. As for the population's living conditions, measured by the levels of poverty in the country, in 2004 the percentage of the Portuguese population at risk of poverty was $27.5 \%$ and in 2018 it was $21.6 \%$, that is, the 13 th highest in the total of the 28 countries.

The low growth of the Portuguese economy and its vulnerability to fluctuations in international markets have led to the fact that at three different moments (1978-1979; 1983-1985; and 2011-2014) Portugal had to call upon the International Monetary Fund (IMF) for assistance in order to solve serious financial crisis (Nunes, 2011; Correia, 2016). The first two times, the reasons behind these calls for assistance were, in 1997, the first oil crisis and, in 1983, the second oil crisis (Lopes, 2004). In April 2011 Portugal became the third country in a row, after Greece and Ireland, to receive a bailout from the 'Troika' of the European Commission (EC), the European Central Bank (ECB) and the International Monetary Fund (IMF). Financial markets began to become suspicious about the ability of the country to fulfil its sovereign debt liabilities, risk premiums increased up to a point where access to capital markets was no longer an option and a debt default soon became imminent. At this point the Portuguese minority Socialist government of José Sócrates had no option other than to negotiate a bailout in the form of a memorandum of understanding with the three lending consortia - the EC, ECB and IMF. (Pereira \& Wemans, 2012).

The austerity programme negotiated with the Troika imposed a series of restrictive measures - tax increases and spending cuts (Caldas, 2012) - which had very visible consequences on the lives of the Portuguese population. One of the most serious was certainly the growth in the unemployment rate, which in 2013 reached a peak of $16.2 \%$, affecting mainly young people under 25 old (38.1\%) (Source: INE - Statistics Portugal). At the same time, wage and pension cuts were approved, which in some cases represented a negative variation in disposable income of more than 25\% (Arnold \& Rodrigues, 2015). The impacts of the financial crisis were also felt in other areas, such as education (cuts in school budgets, decrease in students attending higher education, etc.) and health (decrease in the number of medical appointments, restriction in the purchase of medicines, impact on mental health...). (Sakellarides, Castelo-Branco, Barbosa, Azevedo, 2014). The cumulative effects of the austerity measures strongly affected the living conditions of Portuguese families and worsened the levels of poverty and inequality, which were already high and above the European Union average. However, such effects were not felt with the same severity in all groups of the population.

As Rodrigues, Figueiras \& Junqueira (2016) point out, one of the most common myths about what happened in Portugal in these years was that the crisis was particularly felt by the middle class. And the other is that austerity policies, such as wage and pension cuts, were implemented in order to exempt the poorest families and individuals. The available data shows that the reality was quite different.

According to data collected by INE - Statistics Portugal through the Survey on Income and Living Conditions (EU-SILC), Portugal was, in the set of countries subject to adjustment programs, the one that registered the most moderate decrease in nominal income, between 2009 and 2013: 5\% in Portugal, against 4.3\% in Ireland, 9\% in Spain, and $36.5 \%$ in Greece. This figure hides, however, a very different reality as regards the distribution of this effort among the different groups of households Graph 1 shows that all 
deciles have a decrease in income: the income of the richest $10 \%$ decreases by around $13 \%$, that of deciles 3 to 7 falls between $10 \%$ and $12 \%$, while that of the poorest $10 \%$ decreases $25 \%$. The fact that the cuts in wages and pensions did not directly affected the poorest, having penalised the middle class more, was not enough to offset the negative effects generated by the growth in unemployment and the change in the rules on access to social support provided by the State.

As an immediate consequence of this disequilibrium, the downward cycle of inequality that had been occurring since the beginning of the century was reversed. The S90/S10 ratio compares the income of the poorest $10 \%$ with that of the richest $10 \%$ and reveals the asymmetries between the extremes of income distribution. The evolution of this indicator is similar to that observed for the Gini coefficient. Applied to the Portuguese case, the analysis of the ratio reveals that, if in 2009 the lowest value was reached, where the average income per equivalent adult of the richest $10 \%$ was about 9.2 times higher than that of the lowest income $10 \%$, this value increased to 11.1 times in 2013 Graph 2.

If Portugal has one of the most unequal income distributions in Europe, the crisis has added even more inequality. And, as some analyses (Caldas, 2012; Arnold \& Rodrigues, 2015) point out, the loss of income was more severe at the level of those who already had low levels of wealth.

The fall in family incomes and the increase in inequality over the period of the "structural adjustment" could only have negative repercussions on poverty indicators. Furthermore, because in the European context the poverty rate is calculated as corresponding to the percentage of the population with an income which is equivalent to $60 \%$ of the country's median income. Between 2009 and 2014, the at-risk-of-poverty rate increased by 1.6 p.p., from $17.7 \%$ to $19.5 \%$, representing a total of 2.02 million poor individuals in a total population of around 10 million residents. This percentage was only not higher because, at the same time, the "average income" of the Portuguese population decreased, from which the at-risk-of-poverty rate is calculated (from $434 €$ per month per capita to $422 €$ per month). By groups, the impoverishment process was more felt among unemployed individuals and among households with dependent children (households composed of one adult and one or more dependent children; households composed of two adults with three or more dependent children). Poverty ended up affecting the elderly population less, largely because of social transfers (retirement pensions and others).

The period that follows, between 2015 and 2019, is very different from the previous one. In May 2014 Portugal, 'the Troika's good pupil', was able to return to the markets as scheduled, and exited the assistance programme. The government elected in the legislative elections that took place in October 2015, of a socialist minority but supported by two left parties, began to be pressured to reverse many of the austerity measures that had been taken over the previous period. This was the case with the annulment of pension cuts, an increase of the minimum wage or the establishment of a timetable for the gradual wages replacement (Glatzer, 2018). At the same time, the Portuguese economy began to show signs of improving performance, in line with the signs of recovery in the European and world economies. Also in 2014, the three-year trend of negative GDP growth was reversed, with a positive growth of $3.51 \%$ in 2017 and $2.65 \%$ in 2018 (2016 as the reference year). As for the unemployment rate, after peaking at $16.2 \%$ in 2013 , there was a gradual decrease, falling to $6.5 \%$ in 2019 (latest data available). 
As with other indicators, a downward trend has been restarted in terms of poverty and inequality. With regard to the at-risk-of-poverty population Graph 3, the registered rate went from $19.5 \%$ in 2014 to $17.2 \%$ in 2018 . According to the latest data available (INE - Statistics Portugal, 2019), during 2018 the at-risk-of-poverty rate decreased in particular for those aged less than 18 years old, from $19.0 \%$ in 2017 to $18.5 \%$ in 2018 , and the elderly population from $17.7 \%$ to $17.3 \%$. Despite the decrease of child at-risk-of-poverty rate, the presence of children in a household continues to be associated with a higher risk of poverty in 2018, especially in the case of households composed of one adult with at least one dependent child (33.9\%) and those composed of two adults with three or more dependent children (30.2\%). In terms of inequality, as measured by the S90/S10 ratio Graph 2) there is a similar trend towards a decrease in the distance between the richest and the poorest. In 2018 the ratio was 8.6 , which is the lowest value since records are available.

The positive development in the last 4 years is the reason for moderate optimism. Nevertheless, it is still the case that, in terms of inequality and poverty, Portugal continues to show values above the European Union average. This makes us reflect on the challenges and, above all, on the conditions for achieving a scenario that will transform Portugal into a less poor and less unequal society.

\section{Structural factors}

The financial crisis faced by Portugal between 2011 and 2014 was aggravated by the negative coalition of three factors, the effects of which were directly felt in the worsening of poverty and inequality. We mention specifically the implementation of a reform programme imposed by the Troika as a condition for financial support to the country, the use by the national government of the crisis scenario to implement certain measures that would not otherwise be supported by the population, and also the low opposition of Portuguese society to the execution of the austerity programme.

Austerity and structural adjustment policies inscribed in the Memorandum of Understanding signed between the Troika and the Portuguese government were geared towards reducing the government deficit and debt and rebalancing the current account by cutting wages. The goal of reducing the government deficit was pursued with acrossthe-board tax increases and spending cuts. The main tax increases included: the reduction of tax allowances, increasing all VAT rates (maximum currently 23 per cent), increasing employee contributions to public pension funds and increasing income tax rates. In parallel with this, forms of co-payment were introduced in the National Health Service and the prices of other public services (transport) were increased. As to the main spending cuts: wage cuts in the public administration, cuts in higher pensions, spending cuts in the National Health Service and the Public Education System, the freezing of public investment and the reduction of transfers to public sector firms (Caldas, 2012).

In turn, the government composed by a centre-right coalition took the opportunity to push forward reforms that had little support among the population (Moury \& Freire, 2012; Fonseca \& Ferreira, 2015; Moury \& Stranding, 2017). Acting in counter cycle, the national government reacted to the growth of poverty and social exclusion with the decrease of public support and social benefits. Invoking the need to guarantee the sustainability of the social protection system, the value of social support was reduced and tighter rules 
were introduced for access to it. As a consequence, the number of beneficiaries decreased immediately: in the case of RSI, in 2010 there were 526.382 individuals receiving this social support, and in 2014 the number was 320,554; with regard to child benefit, in 20101.241 .542 children and young people were covered, having decreased to 846.976 beneficiaries in 2014. In contrast, the government's response to social problems focused on an emblematic initiative, the "Social Emergency Plan" (PES) that was implemented from 2011. As the name suggests, the Plan consisted of a list of initiatives designed to mitigate the immediate effects of the economic crisis on Portuguese families, such as an increase in unemployment benefit for couples with children, easier access to medicines at the end of their period of validity, the creation of a social rental market, free distribution of food and the involvement of more social solidarity institutions in the distribution of meals to people and families in need, subsidies for the purchase of school textbooks, and incentives for social volunteering.

In addition to the implementation of measures of an essentially reparative nature and social assistance actions, the government and the different political forces have shown little willingness to discuss solutions of a more structural nature. If in many moments it was stated that the difficulties faced by the Portuguese were necessary sacrifices to save the country from bankruptcy, in others the individual responsibility for the situation was underlined: "A person who is unemployed and has lost his job, something must be wrong, because otherwise he would have kept his job" (TV interview to Prime Minister Passos Coelho, SIC, 2015/07/14). However, in this imputation of individual responsibility the government was not alone, since a significant part of the Portuguese population tends to consider that, in terms of poverty, the responsibility of poor individuals and their family environment overrides factors such as education levels and qualification. Eurobarometer data from 2007 indicated that almost half of the Portuguese population (47\%) considered that poor people have always been poor, which was the highest figure among the $27 \mathrm{EU}$ countries. Just under $1 / 4$ of the population considered it the result of "bad luck" and $1 / 3$ stated that the cause of poverty was "laziness" or "lack of will". In other words, more than half of the Portuguese population attributed the causes of poverty to personal factors.

This characteristic may, in our view, partly explain why throughout the period of crisis Portuguese society has never really mobilised to combat poverty and inequality. And the decision-makers did not feel pressured to do so either.

Regarding what happened after 2014 and the recovery of the downward trend in terms of poverty and inequality in the country, the main explanation lies in the aforementioned positive evolution of the Portuguese economy: increase in economic activity, GDP growth, reinstatement of wages and pensions, significant decrease in unemployment rates, among other signs. Another important variable relates to the impact of redistributive policies, or social transfers, on the reduction of the at-risk-of poverty rate. In 2018, considering only income from employment, propriety and capital property income and private transfers, $43.4 \%$ of Portuguese residents would be at-risk-of-poverty. Income from retirement and survivors' pensions contributed to a 20.7 p.p. rate's decrease. And social transfers related to sickness and disability, family, unemployment, and social inclusion contributed to a reduction of 5.4 p.p. (INE - Statistics Portugal, 2019).

Once again, economic cycles are proving to be decisive in the evolution of inequality and poverty. But they do not detract from the importance of State intervention, whose 
political action and selection of priorities can make a difference. It is in this sense that civil society, namely through the EAPN - European Anti Poverty Network / Portugal, has been demanding from the State a more proactive intervention which puts the fight against poverty and inequality at the centre of political priorities:

“... greater investment in social support and a preventive approach that covers all relevant aspects of well-being and is closer to the people is needed. There are, however, other preconditions that cannot be neglected: intervention in partnership, the territorial approach and integrated intervention. A strategy to combat poverty requires cross-cutting measures and the evaluation of the effects (positive and/or negative) that each policy may have on poverty and exclusion" (EAPN, 2015, p. 12).

The underlying conviction is that, both in terms of causes and solutions, poverty and inequality depend on both economic and social policies.

\section{Lessons for the future}

As we write this article, Portugal, like the rest of the world, faces the Covid-19 pandemic. In addition to the social alarm, a financial crisis with unpredictable consequences is beginning to take shape, which could lead the country to a scenario equal or similar to that of 2011-2014. Regardless of what will happen in the near future, a question arises: in terms of poverty and inequality, should we expect the economy to continue to play its part and eventually help to reduce it, or do we have the duty and the means to invest in a more accelerated reduction path?

Taking into account the Portuguese experience, our perspective is that, if the social crisis was accelerated by the junction of three factors, it may also be the combination of them - a positive alliance between the economy, political deliberation and social mobilization - to enable greater gains in reducing poverty and inequality.

In recent years important scientific works have been published analysing inequality in contemporary societies and proposing measures to reduce it, some of which have turned into surprising bestsellers (Stiglitz, 2012; Piketty, 2014; Atkinson, 2015; Milanovic, 2016). A strong idea shared by several of these authors is that in a future in which "business as usual" continues, global inequality will further increase (Alvaredo, Chancel, Piketty, Saez, Zucman, 2018). Alternatively, reversing inequality trajectory and obtaining substantial progress in eradicating global poverty implies a reduction in market income inequality, which is possible if the governments prosecute a significant influence on market incomes. But the government's impact will be most direct in the case of redistributive taxation and the provision of social security. As such, they put forward proposals that focus on a more redistributive policy, namely through increased taxation of wealth (Pikkety) or via a capital endowment (minimum inheritance) paid to all adulthood (Atkinson). On the side of social protection measures, the introduction of a universal minimum income or the extension of social insurance is suggested. Other proposed measures include educational policies, corporate governance and wage-setting policies. Data transparency is also key.

We believe that greater State intervention is desirable, particularly to compensate for the inequalities generated by a competitive market that provides very unequal opportunities and gains. But we also believe that the State cannot and should not be alone in determining the most appropriate policies. A transversal approach is needed that involves and commits 
other stakeholders in the fight against poverty and inequality, in which we identify four priorities: a) strengthening citizenship and the participation of civil society, with a view to good governance; $b$ ) listening to and encouraging the active participation of citizens in poverty; c) territorialising measures and promoting integrated local intervention (Monteiro, 2014); d) monitoring phenomena and assessing the impacts of the implemented measures.

Beyond the constant fluctuations of the open and competitive market, in recent decades we have been witnessing the decharacterization of the Social State, which has been transformed into a system of minimalist protection and subsidiary to private protection. At the same time, and within the framework of a "risk society" (Beck, 1986), there has been a weakening of solidarity mechanisms and of the regulatory and mediating action of certain fundamental social bodies (family, state, school, associations, professional corporations). Under this line of thought, the fight against poverty and inequality, and the (re)achievement of social cohesion, go through (not only, but also) a greater articulation between the bodies concerned, and between them and the individuals. The reconfiguration of institutional relations appears as an opportunity to recreate fundamental links of solidarity, of regaining confidence in institutions, of citizens' participation and empowerment, of shared responsibility and mutual accountability. At the same time, it is at issue the assumption of a collective commitment on the desired level of inequality and the salvation of a deliberative democracy (Piketty, 2019) that is not hostage to the decision of a few over many. We also believe that this can be one of the formulas to limit extremism and renew democracy. 
Алсидес А. Монетеиро ${ }^{1}$

Универзитет Беира Интериор (УБИ)

Факултет друштвено-хуманистичких наука

Центар за истраживање и студије социологије

Ковиља (Португалија)

\title{
СИРОМАШТВО И НЕЈЕДНАКОСТ У САВРЕМЕНОЈ ПОРТУГАЛИЈИ: УТИЦАЈ ПОЛИТИКА ШТЕДЊЕ И ЛЕКЦИЈЕ ЗА БУДУЋНОСТ
}

\author{
(Превоg In Extenso)
}

Сажетак: У Европској унији, Португалија је једна од земаља с највишим нивоима сиромаштва и неједнакости. То је стварност која ће бити у фокусу овог рада. Текст даје статистичке податке који илуструју развој сиромаштва и неједнакост прихода током последње деценије (2011-2019), а послужиће као основ за критичку анализу последица економских циклуса. Пре свега, то се односи на начин на који је спој економије (финансијска криза), политике (план штедње) и социјалног контекста (недостатак социјалног такмичења) утицао на погоршање током периода 2011-2014. Из анализе можемо да развијемо аргумент да уколико негативан спој ова три фактора чини земљу сиромашнијом и са више неједнакости, позитиван спој истих фактора могао би заузврат да доведе до значајног напретка у борби против сиромаштва и социјалне неједнакости.

Кључне речи: Португалија; сиромаштво; неједнакост прихода; економски циклуси; статистика

\section{Увод}

Социјална неједнакост, сиромаштво, али и социјална исљученост, представљају изазов за свако друштво које треба да покаже најбоље што може да постигне у смислу колективне мобилизације, консолидације демократије и промовисања социјалне кохезије. Није могуће истовремено исказивати тежњу ка здравој демократији и толерисати велике социјалне неједнакости и неприхватљиве стопе сиромаштва. У Португалији, међутим, влада атмосфера порицања озбиљности ових социјалних проблема, повезана са срамотом због датих ситуација и одговорношћу осталих. Понављају се тврдње попут: „Не постоје сиромашни људи”, „Неједнакост је била много гора у прошлости” или „Они су искључени зато што тако желе”. Ово је, с друге стране, супротно стастистичким налазима да земља и даље има високе нивое сиромаштва и неједнакости. У контексту 28 држава у саставу Европске уније, којој је Португалија приступила 1986. године, она се налази на 13. месту по стопи угрожености

\footnotetext{
${ }^{1}$ alcidesmonteiro@ubi.pt
} 
услед сиромаштва. Ипак, чини се да је Португалија у неповољнијој ситуацији када је реч о неједнакој распоређености прихода, на 10. месту те скале (подаци из 2018. године, извор: INE - Статистички завод Португалије).

Последњу деценију у Португалији, између 2011. и 2019, обележила су два јасно изражена циклуса. Током прве половине деценије, земља је доживела снажну финансијску и социјалну кризу, за време процеса у којем је влада морала да се обрати за помоћ међународним зајмодавцима („Тројство” које чине Комисија ЕУ, Међународни монетарни фонд и Европска централна банка) како би избегао банкрот и вратио међународни кредибилитет. Сценарио са којим се влада суочила био је негативан спој три фактора, што је имало директне последице на погоршање сиромаштва и неједнакости током читавог овог периода: прво, примена низа реформи „структурног прилагођавања” које је наметнуло горепоменуто „Тројство”; друго, начин на који је национална влада искористила аргумент кризе како би спровела неке мере које у неком другом контексту не би имале подршку становништва; и, на крају, чињеница да се португалско друштво није директно успротивило примени мера штедње, помиривши се са сиромаштвом, што је утицало пре свега на оне који су већ били угрожени. Од 2015. године сценарио је промењен, земља је изашла из кризе и ослободила се менторства које су наметнула три зајмодавца; почео је привредни опоравак, а нивои сиромаштва и неједнакости поново су почели да опадају. Јасно је, међутим, да је овај тренд углавном резултат повољне економске климе, а не неког политичког програма или мобилизације грађана у циљу решавања и превазилажења тих социјалних проблема.

Португалију у новијој историји можемо посматрати као пример односа између економских циклуса и развоја сиромаштва и неједнакости. Ипак, у исто време се испоставља да расту или паду нивоа неједнакости не доприноси само економија, већ и политичке одлуке и социјална динамика. Сходно томе, у овом тексту смо поставили двоструки циљ: с једне стране, треба дати приказ развоја феномена сиромаштва и неједнакости током последње деценије у Португалији у два кључна тренутка; с друге стране, треба анализирати како је спој економије, политичких одлука и социјалног контекста утицао на горепоменути развој. У последњој инстанци, наш аргумент је да ако негативни спој ова три фактора чини земљу сиромашнијом и са више неједнакости, позитиван спој истих фактора могао би заузврат да доведе до значајног напретка у борби против сиромаштва и социјалне неједнакости.

\section{Португалија, 2011-2019: економски циклуси и развој сиромаштва и неједнакости}

Португалија је постала члан тзв. Европске економске заједнице (енгл. EE0C) 1. јануара 1986. године. Од тог тренутка до 1991. године земља је имала користи од периода транзиције јер је ниво развоја земље био нижи у односу на остале чланице. Како би се превазишла та неједнакост, Португалија је од Европске економске заједнице добила структурна средства која су влади омогућила да предузме неопходне реформе, између осталог, за модернизацију производног сектора, стварање инфраструктуре, унапређење здравства и ширење образовне мреже. У овом, као и у наредним периодима, развој португалске економије као и животних услова становништва 
био је очигледно позитиван. И поред тога, није био довољан да би се гарантовало његово изједначавање са осталим државама чланицама (Cunha \& Braz, 2009). На пример, 1995. је португалски БДП по глави становника износио 79\% просека у Европској унији (узевши у обзир 28 држава које су чиниле ЕУ у јануару 2020). Године 2019. БДП по глави становника износио је 77\% просека у Европској унији. Када је реч о животним условима становника, измереним према нивоима у земљи, проценат португалских становника којима је претило сиромаштво је 2004. износио 27,5\% а 2018. године 21,6\%, односно на 13 . месту од укупно 28 земаља.

Низак раст португалске економије и њена осетљивост на флуктуације на међународним тржиштима довела је до тога да је у три различита периода (1978-1979, 1983-1985 и 2011-2014) Португалија морала да се обрати за помоћ Међународном монетарном фонду како би решила озбиљну финансијску кризу (Nunes, 2011; Correia, 2016). У два наврата, разлози за ове позиве за помоћ били су прва нафтна криза 1997. и друга нафтна криза 1983. године (Lopes, 2004). У априлу 2011. Португалија је била трећа земља у низу, после Грчке и Ирске, којој је помогло „Тројство” сачињено од Европске комисије, Европске централне банке и Међународног монетарног фонда. Финансијска тржишта почела су да сумњају у способност ове земље да испуни своје обавезе у погледу државног дуга; премије ризика повећане су до тачке где приступ тржиштима капитала више није био опција, а неотплаћивање дуга ускоро је постало неминовно. У том тренутку мањинска социјалистичка влада у Португалији коју је предводио Хосе Сократес није имала другог избора осим да преговара о томе како да се спаси, потписавши меморандум о разумевању са водећа три конзорцијума Европском комисијом, Европском централном банком и Међународним монетарним фондом (Pereira \& Wemans, 2012).

Програм штедње договорен са „Тројством” наметнуо је низ рестриктивних мера - повећање пореза и смањење потрошње (Caldas, 2012) - што је имало видне последице на живот Португалаца. Једна од најозбиљнијих последица свакако је био раст стопе незапослености која је 2013. достигла рекордних 16,2\%, погађајући углавном младе људе до 25 година старости (38,1\%) (Извор: INE - Статистички завод Португалије). Истовремено су одобрена смањења плата и пензија, што је у појединим случајевима представљало негативну варијацију у расположивом приходу од преко 25\% (Arnold \& Rodrigues, 2015). Утицаји финансијске кризе осетили су се и у другим областима, као што су образовање (резови у школским буџетима, смањење броја студената у вишем образовању итд.) и здравство (смањење броја заказаних прегледа, ограничена куповина лекова, утицај на ментално здравље...) (Sakellarides, Castelo-Branco, Barbosa, Azevedo, 2014). Кумулативни ефекти мера штедње снажно су утицали на услове живота португалских породица и погоршали нивое сиромаштва и неједнакости који су већ били високи и изнад просека Европске уније. Ти ефекти, међутим, нису се осетили истим интензитетом у свим групама становништва.

Као што Родригес, Фигеирас и Хунхеира (Rodrigues, Figueiras \& Junqueira, 2016) истичу, један од најраспрострањенијих митова о томе шта се догађало у Португалији тих година био је да је кризу посебно осетила средња класа. Други мит јесте да су политике штедње, попут смањења плата и пензија, спроведене тако да се изузму најсиромашније породице и појединици. Доступни подаци показују да је у стварности било сасвим другачије. 


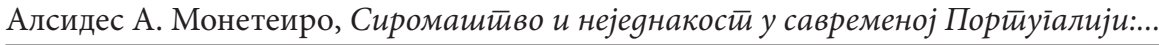

Према подацима које је сакупио Статистички завод Португаије (INE) путем Анкете о приходу и условима живота (EU-SILC), у Португалији је, од свих држава подвргнутих програмима прилагођавања, забележено најумереније смањење номиналног прихода у периоду 2009-2013: 5\% у Португалији у односу на 4,3\% у Ирској, 9\% у Шпанији и $36,5 \%$ у Грчкој. Ова цифра, међутим, крије сасвим другачију стварност у погледу распоређености ових напора међу различитим групама домаћинстава. Графикон 1 показује да сви децили имају смањење прихода: приход најбогатијих 10\% смањен је за око 13\%, приход децила од 3 до 7 пао је између 10\% и 12\%, док је код оних најсиромашнијих 10\% пао за 25\%. Чињеница је да смањење плата и пензија није директно утицало на најсиромашније, док је више казнило средњу класу, али није било довољно да спречи негативне утицаје услед пораста незапослености и промене правила о приступу социјалној помоћи коју обезбеђује држава.

Као непосредна последица ове неравнотеже, преокренут је силазни циклус неједнакости који је био присутан од почетка века. Однос S90/S10 упоређује приход најсиромашнијих 10\% са приходом најбогатијих 10\% и открива асиметрије између крајњих вредности распоређености прихода. Кретање овог показатеља слично је ономе које је примећено за Џини коефицијент. Када се примени на случај Португалије, анализа овог односа открива да, ако је најнижа вредност достигнута 2009, када је просечан приход по еквивалентној одраслој особи код најбогатијих $10 \%$ био око 9,2 већи него код 10\% с најнижим приходом, ова вредност је повећана 11,1 пута 2013. године.

Ако Португалија предњачи у неравомерној распоређености прихода у Европи, криза је донела додатну неједнакост. Као што неке анализе показују (Caldas, 2012; Arnold \& Rodrigues, 2015), губитак прихода био је још упадљивији на нивоу оних који су већ имали низак степен богатства.

Пад у породичним приходима и повећана неједнакост током периода „структурног прилагођавања” могли су да имају само негативне последице на показатеље сиромаштва. Исто тако, треба имати у виду да се у европском контексту стопа сиромаштва обрачунава у односу на проценат становништва са приходом који је еквивалентан 60\% средњег прихода у држави. Између 2009. и 2014, стопа ризика од сиромаштва порасла је за 1,6 процентних поена, са 17,7\% на 19,5\%, што чини укупно 2,02 милиона сиромашних појединаца од укупног броја од 10 милиона становника. Овај проценат није био додатно већи само зато што је, у исто време, смањен „просечан приход” Португалаца, на основу којег се обрачунава стопа ризика од сиромаштва (са $434 €$ по становнику месечно на $422 €$ месечно). Према групама, процес осиромашења највише су осетили незапослени појединци и домаћинства с малолетном децом (домаћинства састављена од једне одрасле особе с једним дететом или више деце која зависе од те особе). На крају је сиромаштво мање погодило старију популацију, углавном због социјалних трансфера (старосне пензије и остало).

Период који је уследио, између 2015. и 2019, потпуно је другачији од претходног. У мају 2014. Португалија је, као „добар ученик Тројстива”, успела да се врати на тржишта како је било предвиђено и изашла је из програма помоћи. На владу изгласану на законодавним изборима у октобру 2015. године, која је представљала социјалистичку мањину, али уз подршку две левичарске партије, извршени су притисци да укине бројне мере штедње из претходног периода. Ово је био случај с укидањем 
смањења пензија, повећањем минималног дохотка и увођењем распореда за постепену замену зарада (Glatzer, 2018). У исто време, португалска економија почела је да показује знаке побољшаног учинка, у складу са знацима опоравка у европској и светској економији. Исто тако, 2014. је заустављен трогодишњи тренд негативног раста БДП-а, с позитивним растом од 3,51\% током 2017. и 2,65\% током 2018. године (2016. је узета као референтна година). Што се тиче стопе незапослености, после највеће вредности од 16,2\% у 2013, уследио је постепени пад, те је ова стопа 2019. године износила 6,5\% (последњи доступни подаци).

Као и код осталих показатеља, силазни тренд поново је забележен у сиромаштву и неједнакости. Када је реч о становништву изложеном ризику од сиромаштва (Графикон 3), забележена стопа порасла је са 19,5\% током 2014. на 17,2\% током 2018. године. Према најновијим доступним подацима (INE - Статистички завод Португалије, 2019), током 2018. је стопа ризика од сиромаштва смањена нарочито код оних млађих од 18 година, и то са 19,0\% током 2017. на 18,5\% током 2018, а код старијих становника са 17,7\% на 17,3\%. Упркос смањеној стопи ризика од сиромаштва код деце, присуство деце у домаћинству и даље се повезује са повећаним ризиком од сиромаштва у 2018, посебно у случају домаћинстава састављених од једне одрасле особе и с минимум једним издржаваним дететом $(33,9 \%)$ и домаћинстава с две одрасле особе и троје или више издржаване деце (30,2\%). Када је реч о неједнакости измереној према односу S90/S10 [рафикон 2), забележен је сличан тренд према смањењу разлике између најбогатијих и најсиромашнијих. Године 2018. тај однос износио је 8,6, што је најнижа вредност од када се бележе статистички подаци.

Позитиван развој у последње четири године представља разлог за умерен оптимизам. Но ипак, када је реч о неједнакости и сиромаштву, Португалија и даље има вредности изнад просека Европске уније. Ово нас наводи на размишљање о изазовима и, пре свега, о условима за остваривање сценарија који ће трансформисати Португалију у друштво с мање сиромаштва и неједнакости.

\section{Структурни фактори}

Финансијска криза са којом се Португалија суочила од 2011. до 2014. погоршана је због негативног споја три фактора, чији су се утицаји директно осетили у повећаном сиромаштву и неједнакости. Овде ћемо конкретно навести спровођење програма реформи које је наметнуло „Тројство” као услов за финансијску подршку земљи, примена сценарија од стране владе у циљу спровођења одређених мера које становништво у противном не би подржало, као и слабо противљење португалског друштва спровођењу програма штедње.

Политике штедње и структурног прилагођавања предвиђене Меморандумом о разумевању између „Тројства” и португалске владе биле су усмерене на смањење државног дефицита и задужености и на ребаланс постојећег стања смањењем зарада. У циљу смањивања државног дефицита повећани су прекогранични порези и смањена је потрошња. Главна пореска повећања обухватила су: смањење пореских олакшица, повећање свих стопа ПДВ-а (максимум тренутно износи 23 посто), повећање доприноса запослених за државни пензиони фонд и повећање стопе пореза на приход. Паралелно са тим, Национални здравствени систем увео је и облике 
доплате, односно удруженог плаћања здравствених услуга, а повећане су и цене осталих јавних услуга (превоз). Главна смањења потрошње обухватила су: смањење зарада у државној администрацији, смањење великих пензија, смањење потрошње у Националном здравственом систему и Систему државног образовања, замрзавање јавних инвестиција и смањење трансфера на фирме у јавном сектору (Caldas, 2012).

С друге стране, влада као коалиција центра и десног крила искористила је прилику да уведе реформе које су имале недовољну подршку становништва (Moury \& Freire, 2012; Fonseca \& Ferreira, 2015; Moury \& Stranding, 2017). Поступајући у контра-циклусу, национална влада је реаговала на пораст сиромаштва и социјалне искључености тако што је смањила државну помоћ и социјалне олакшице. Због потребе да се гарантује одрживост система социјалне заштите, смањен је износ социјалне помоћи и уведена су строжа правила за добијање те помоћи. Као последица, број корисника је одмах смањен: у случају RSI, 2010. године било је 526.382 особе које су добијале социјалну помоћ, док је тај број 2014. износио 320.554; када је реч о дечјем додатку, 2010. га је добијало 1.241.542 деце и омладинаца, да би број корисника пао на 846.976 током 2014. године. Насупрот томе, одговор владе на социјалне проблеме био је усредсређен на иницијативу под називом „Ванредни план за социјална питања" (PES) који је уведен 2011. године. Као што само име указује, план се састојао од листе иницијатива предвиђених да ублаже непосредне утицаје економске кризе на португалске породице, на пример повећање доприноса за незапосленост паровима са децом, лакша доступност лекова којима ускоро истиче рок употребе, стварање тржишта социјалног закупа, бесплатна дистрибуција хране и укључивање већег броја институција социјалне солидарности у обезбеђивање оброка сиромашним појединцима и породицама, субвенције за куповину школских уџбеника и подстицаји за социјално волонтирање.

Поред мера, у суштини, репаративне природе и акција социјалне помоћи, влада и разне политичке снаге нису показале довољну спремност да разговарају о решењима која су пре свега структурна. У одређеним тренуцима се тврдило да су тешкоће пред Португалцима неопходна жртва како би се спречило банкротство државе, а касније је наглашавана појединачна одговорност за ситуацију: „Ако је особа незапослена, односно ако је изгубила посао, нешто дефинитивно није у реду са том особом јер би у супротном задржала посао" (телевизијски интервју премијера Пасоса Коеља, SIC, 14. јул 2015). Влада није била усамљена у том истицању појединачне одговорности, јер значајан део португалског становништва сматра да је, у погледу сиромаштва, одговорност сиромашних појединаца и њихових породица много важнија од фактора као што су степен образовања и квалификације. Подаци Еуробарометра из 2007. указали су на то да готово половина Португалаца (47\%) сматра да су сиромашни одувек били сиромашни, те да је тај проценат највећи у односу на осталих 27 чланица ЕУ. Нешто мање од четвртине становништва сматрало је да је то резултат „лоше среће”, док је трећина изјавила да узрок сиромаштва лежи у „лењости” или „недостатку воље”. Другим речима, више од половине Португалаца приписало је узроке сиромаштва личним факторима.

Ова карактеристика може, по нашем мишљењу, делимично да одговори на питање зашто се током читавог периода кризе португалско друштво никада није 
мобилисало како би се борило против сиромаштва и неједнакости. Притом, ни доносиоци одлука нису били под притиском да то учине.

Када је реч о догађајима после 2014. и опоравку силазног тренда у погледу сиромаштва и неједнакости у земљи, главно објашњење може се наћи у већ поменутом позитивном развоју португалске економије: повећање економске активности, раст БДП-а, враћање плата и пензија на претходни ниво, значајно смањење стопе незапослености, као неким од показатеља. Још једна значајна варијабла односи се на утицај редистрибутивних политика, односно социјалних трансфера, на смањење стопе ризика од сиромаштва. Године 2018, када се узме у обзир само приход од запослености, имовине и капиталне имовине и приватних трансфера, 43,4\% Португалаца било је изложено ризику од сиромаштва. Приход од старосних пензија и пензија наследника допринео је смањењу ове стопе за 20,7 процентних поена. Социјални трансфери повезани са болешћу и инвалидитетом, породицом, незапосленошћу и социјалном инклузијом допринели су смањењу ове стопе за 5,4 процентна поена (INE - Статистички завод Португалије, 2019).

Још једном се доказало да су економски циклуси одлучујући у развоју неједнакости и сиромаштва. Ипак, они не умањују значај државне интервенције јер се њеном политичком акцијом и одабиром приоритета може направити разлика. У том смислу, цивилно друштво у Португалији, превасходно преко Европске мреже против сиромаштва (EAPN), захтева од државе проактивнију интервенцију која ће борбу против сиромаштва и неједнакости ставити у средиште политичких приоритета:

„... већа улагања у социјалну подршку и превентивни приступ који обухвата све релевантне аспекте благостања и ближи је људима који оскудевају. Међутим, постоје и остали предуслови који се не могу занемарити: удружена интервенција, територијални приступ и интегрисана интервенција. Стратегија за борбу против сиромаштва захтева повезане мере и процену утицаја (позитивних и/или негативних) које свака политика може да има на сиромаштво и искљученост" (EAPN, 2015, str. 12).

У основи је убеђење да, како у погледу узрока, тако и решења, сиромаштво и неједнакост зависе подједнако од економских и социјалних политика.

\section{Лекције за будућност}

У тренутку док пишемо овај чланак, Португалија је, као и остали делови света, суочена са пандемијом Covid-19. Осим панике у друштву, полако се назире финансијска криза са непредвидим последицама, која би могла да увуче земљу у сценарио идентичан или сличан ономе из 2011-2014. године. Без обзира на то шта ће се догодити у блиској будућности, поставља се питање: када говоримо о сиромаштву и неједнакости, да ли би требало очекивати да ће економија и даље имати своју улогу и на крају помоћи да се сиромаштво и неједнакост смање, или да ли имамо дужност и средства за улагање у бржи план за њихово ублажавање.

Када се узме у обзир португалско искуство, наше мишљење је да, ако се социјална криза убрза услед споја три фактора, управо њихов спој - позитивна повезаност економије, политичког дијалога и социјалне мобилизације - могао би да омогући боље резултате у ублажавању сиромаштва и неједнакости. 


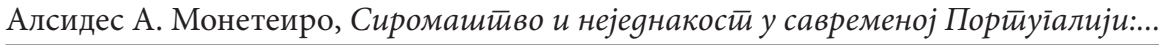

У последње време објављени су значајни научни радови који анализирају неједнакост у савременим друштвима и предлажу мере за њено смањење, а неки од тих радова постали су прави бестселери (Stiglitz, 2012; Piketty, 2014; Atkinson, 2015; Milanovic, 2016). Упадљива идеја коју дели неколико аутора јесте да ће се у будућности у којој ће се наставити „уобичајено пословање”, глобална неједнакост и даље повећавати (Alvaredo, Chancel, Piketty, Saez, Zucman, 2018). С друге стране, мењање путање неједнакости и постизање значајног напретка у искорењивању глобалног сиромаштва подразумева смањење неједнакости тржишних прихода, што је могуће уколико владе изврше значајан утицај на тржишне приходе. Утицај владе биће најдиректнији у случају редистрибутивног опорезивања и обезбеђивања социјалне помоћи. Самим тим, ови аутори дају предлоге који су усредсређени на редистрибутивнију политику, превасходно путем повећаног опорезивања богатства (Pikkety) или путем капиталних доприноса (минимално наслеђивање) исплаћених свим одраслим лицима (Atkinson). Када је реч о мерама социјалне заштите, предлаже се увођење универзалног минималног дохотка или проширивање социјалног осигурања. Остале предложене мере обухватају образовне политике, корпоративно управљање и политике одређивања зарада. Кључна је и транспарентност података.

Уверени смо да је пожељна већа државна интервенција, нарочито да би се ублажиле неједнакости које је произвело конкурентно тржиште са неједнаким могућностима и добитима. Верујемо да држава не може и не треба да буде сама приликом утврђивања најприкладнијих политика. Неопходан је трансверзални приступ који укључује и обавезује остале заинтересоване стране на борбу против сиромаштва и неједнакости, при чему препознајемо четири приоритета: а) учвршћивање грађанства и учешћа цивилног друштва у циљу доброг управљања; б) уважавање и подстицање активног учешћа грађана у погледу сиромаштва; в) мере територизације и подстицање интегрисане локалне интервенције (Monteiro, 2014); г) праћење појава и процена утицаја спроведених мера.

Поред сталних флуктуација на отвореном и конкурентном тржишту, у последњим деценијама сведоци смо декарактеризације социјалне државе која је трансформисана у систем минималне заштите помоћне приватне заштите. Истовремено, у оквиру „ризичног друштва” (Beck, 1986), дошло је до слабљења механизама солидарности и регулаторне и посредничке акције појединих основних друштвених тела (породица, држава, школа, удружења, стручне корпорације). Пратећи ову линију размишљања, борба против сиромаштва и неједнакости и (поновно) постизање социјалне кохезије постају (не само, већ и) артикулисанији између релевантних тела, као и између тих тела и појединаца. Чини се да преобликовање институционалних односа представља прилику да се поново успоставе фундаменталне везе солидарности, враћање поверења у институције, учешће и оснаживање грађана, заједничке и узајамне одговорности. Истовремено се наводи претпоставка о колективној посвећености неједнакости на жељеном нивоу и о очувању демократске расправе (Piketty, 2019) која неће зависити од одлуке мањине у односу на већину. Верујемо да ово може бити једна од формула за ограничавање екстремизма и обнављање демократије. 


\section{REFERENCES / ЛИTEPATУРA}

Arnold, J., Rodrigues, C. F. (2015). Reducing inequality and poverty in Portugal. OECD Economics Department Working Papers, No. 1258. Paris: OECD Publishing. doi: 10.1787/5jrw21ng3ts3-en

Atkinson, A. B. (2015). Inequality - What Can Be Done?. London: Harvard University Press.

Caldas, J. C. (2012). The Consequences of Austerity Policies in Portugal, FES International Policy Analysis. Berlin: Friedrich Ebert Foundation.

Correia, L. (2016). The European Crisis: Repercussions on the Portuguese Economy. Athens Journal of Mediterranean Studies, 2(2), 129-144.

Cunha, J., Braz, C. (2009). The main trends in public finance developments in Portugal: 1986-2008. Occasional Paper no 1. Lisbon: Bank of Portugal.

European Anti-Poverty Network [EAPN] et al (2015), Eradicating Poverty: Commitment to a National Strategy. Porto: EAPN. [in Portuguese].

European Commission (2007). Special Eurobarometer 279 - Poverty and Exclusion. Brussels, European Commission.

Fonseca, P., Ferreira, M.J. (2015). Through, 'seas never before sailed': Portuguese government discursive legitimation strategies in a context of financial crisis. Discourse and Society 26 (6), 682-711.

Glatzer, M. (2018). Portugal's Social and Labour Market Policy: The Crisis, the Troika and Beyond. Portuguese Studies 34 (1), 104-118.

INE - Statistics Portugal (2019). Income and Living Conditions 2019 (Provisional data). Lisbon: INE - Statistics Portugal.

Lopes, J. D. (2004). The Portuguese Economy since 1960. Lisbon: Gradiva Publicações, Lda. [in Portuguese].

Milanovic, B. (2016). Global Inequality: A New Approach for the Age of Globalization. London: Harvard University Press.

Monteiro, A. (2014). The Active Role of Community-Based Organizations in the Local Redefinition of National Policies. Revista de Cercetare si Interventie Sociala no 46, 203-215. Avaliable at https://www.rcis.ro/images/documente/rcis46_15.pdf

Monteiro, A. A. (2019). Understanding Social Exclusion. Lisbon: Mundos Sociais. [in Portuguese].

Moury, C., Freire, A. (2013). Austerity Policies and Politics: The Case of Portugal. Pôle Sud $n^{\circ} 39,35-56$.

Moury, C., Standring, A. (2017). 'Going beyond the Troika': Power and discourse in Portuguese austerity. European Journal of Political Research n. 56, 660-679. doi: 10.1111/1475-6765.12190

Nunes, A. B. (2011). The International Monetary Fund's stand-by arrangements with Portugal. An ex-ante application of the Washington Consensus? Lisbon: GHES.

Pereira, P. T., Wemans, L. (2012). Portugal and the global financial crisis: short-sighted politics, deteriorating public finances and the bailout imperative. ISEG Working papers, WP 26/2012/DE/UECE. Lisbon: ISEG.

Piketty, T. (2014). Capital in the 21st Century. Cambridge: Harvard University Press. 


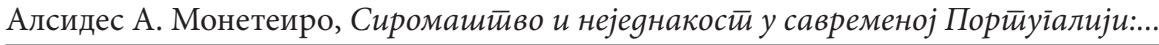

Piketty, T. (2019, November 29). "I propose a tax that would give everyone 120,000 euros over 25 years", interview by Marc Bassets. El País - Ideas Supplement 29 november 2019. Available at https://elpais.com/elpais/2019/11/22/ideas/1574426613_189002. html.

Rodrigues, C. F., Figueiras, R., Junqueira, V. (2016). Introduction to the study - Inequality of Income and Poverty in Portugal, 2009-2014. Lisbon: FFMS. [in Portuguese].

Sakellarides, C., Castelo-Branco, L., Barbosa, P., Azevedo, H. (2014). The impact of the financial crisis on the health system and health in Portugal. Copenhagen: World Health Organization. 


\section{ПРИЛОЗИ / APРЕNDIX}

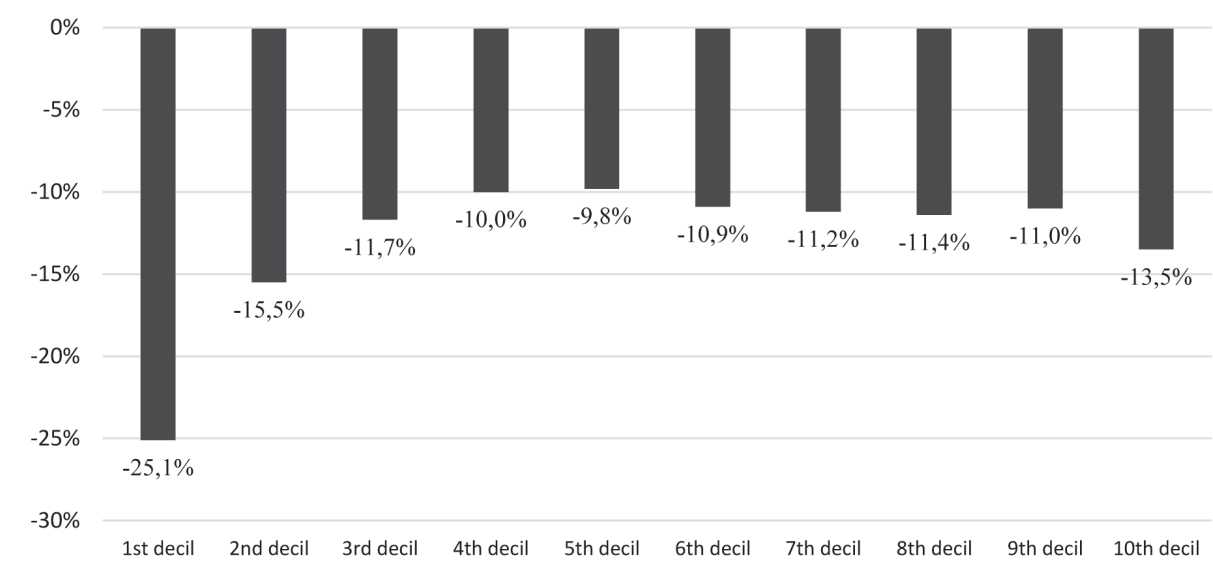

Graph 1: Variation in real disposable income, per equivalent adult, by deciles, 2009-2014 Графикон 1: Варијација стварно расположивог прихода по еквивалентној одраслој особи, према децилима, 2009-2014.

Source: Rodrigues, Figueira \& Junqueira, 2016

14

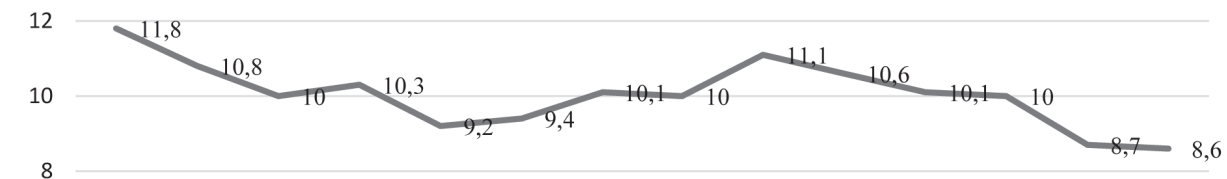

НАЗАД

6

4

2

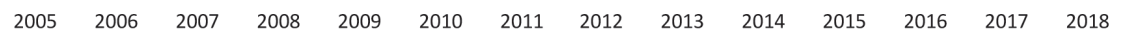

Graph 2: Evolution of the S90 / S10 ratio, 2005-2018

Графикон 2: Развој S90 / S10 односа, 2005-2018.

Source: INE - Survey on Income and Living Conditions, 2005-2018 


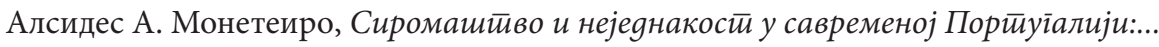

21

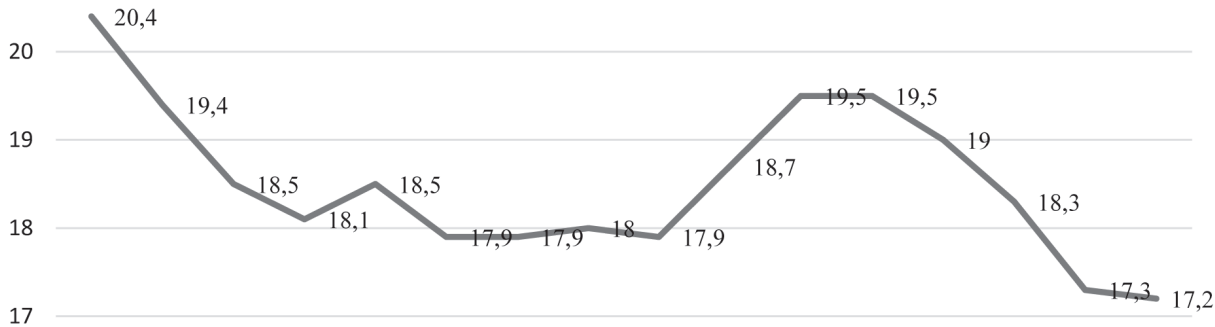

16

15

$\begin{array}{llllllllllllllll}2003 & 2004 & 2005 & 2006 & 2007 & 2008 & 2009 & 2010 & 2011 & 2012 & 2013 & 2014 & 2015 & 2016 & 2017 & 2018\end{array}$

Graph 3: At-risk-of-poverty rate, after social transfers, 2003-2018

Графикон 3: Стопа ризика од сиромаштва, после социјалних трансфера, 2003-2018.

Source: INE - Survey on Income and Living Conditions, 2003-2018 